ISSN 1392-3196 / e-ISSN 2335-8947

Zemdirbyste-Agriculture, vol. 107, No. 4 (2020), p. 317-322

DOI 10.13080/z-a.2020.107.040

\title{
The suitability of perennial grasses for combustion as influenced by chemical composition and plant growth stage
}

\author{
Kristina AMALEVICIUTE-VOLUNGE, Alvyra SLEPETIENE, Bronislava BUTKUTE \\ Lithuanian Research Centre for Agriculture and Forestry, Institute of Agriculture \\ Instituto 1, Akademija, Kèdainiai distr., Lithuania \\ E-mail: kristina.amaleviciute-volunge@lammc.lt
}

\begin{abstract}
The aim of the study was to evaluate six perennial grass species: lucerne (Medicago sativa L.), reed canary grass (Phalaris arundinacea L.), tall fescue (Festuca arundinacea Schreb.), $\operatorname{cocksfoot}$ (Dactylis glomerata L.), switchgrass (Panicum virgatum L.) and ryegrass (Lolium perenne L.), with a balanced composition of organic compounds and minerals, for their suitability for direct combustion in relation to grass species, chemical composition and growth stage. At the regrowth and heading / inflorescence emergence stages, the chemical composition of the biomass of the tested grass species was similar. Before regrowth in spring, the plants contained higher concentrations of carbon, lignin and cellulose and the smallest amounts of ash and nitrogen. Of all the grass species tested, the biomass of lucerne, tall fescue and particularly ryegrass was the most suitable for direct combustion, as it had the highest concentration of carbon $(57.55 \%)$ and the lowest concentration of nitrogen $(0.61 \%)$ and ash $(4.48 \%)$.

The findings suggested that the heating value of the biomass was determined by plant growth stage and chemical composition. It was the highest at the heading stage and before regrowth in spring. It was found that the biomass of lucerne produced the highest energy yield of $303 \mathrm{GJ} \mathrm{ha}^{-1}$ (a sum of two harvests). The biomass of tall fescue produced $185.2 \mathrm{GJ} \mathrm{ha}^{-1}$, and that of cocksfoot $-137.3 \mathrm{GJ} \mathrm{ha}^{-1}$. The biomass of reed canary grass produced a lower energy yield of $93.3 \mathrm{GJ}^{-1}$. The analysis of the relationship between the heating value and chemical composition of the biomass showed a strong correlation between the heating value and acid detergent lignin (ADL) $0.548^{* *}$ $(p<0.01)$. The heating value was also found to positively correlate $(p<0.05)$ with cellulose $\left(0.376^{*}\right)$ and carbon $(0.258 *)$.
\end{abstract}

Key words: bioenergy potential, biomass, heating value, combustion, energy plant.

\section{Introduction}

Perennial grasses are attractive as a source of biomass for Northern Europe, as they meet agronomic, environmental and societal requirements for successful deployment as energy grass crops (Tilvikiene et al., 2016; Kadžiulienè et al., 2017; De Laporte, Ripplinger, 2019). In 2030, the share of energy from renewable sources in the final energy consumption balance of Lithuania will be $45 \%$, although the target will be $80 \%$ by the year 2050 (Gaigalis, Katinas, 2020). Lithuania will continue development of the renewable energy sector (Černiauskienè et al., 2018).

Biomass is the most important source to increase the production of energy based on renewable energy sources (Román-Figueroa et al., 2017). Combustion is the main technology applied to produce heat and energy from biomass and is generally economically feasible. The combustion of biomass as fuel has many environmental and economic advantages. It is cheap, clean and renewable source of energy (Erol et al., 2010; Slepetys et al., 2012; Butkute et al., 2015).

Biomass types are composed of numerous constituents that have complex structures. With respect to chemical and physical properties, biomass species and harvest time have large differences. Hemicellulose, cellulose, lignin and extractive matter are the major constituents of biomass, which are present in different ratios and structures in different biomass species. The heating value of biomass is an indicator of the energy chemically bound in it, and in the combustion process it is converted into heat energy (Kadžiulienè et al., 2017; Nazli, Tansi, 2019; Sosa et al., 2019).

Perennial herbaceous plants are of special importance, as their establishment and cultivation costs are generally much lower than those of annual plants. Perennial plants that have been comprehensively studied in Lithuania are indigenous, naturally occurring species such as tall fescue, cocksfoot and reed canary grass (Tilvikiene et al., 2012; Slepetiene et al., 2016; Tilvikiene et al., 2016), switchgrasses (Norkevičienė et al., 2016). Agricultural researchers are focusing their attention on perennial plants (Slepetys et al., 2012; Butkute et al., 2014; 2015; Tilvikiene et al., 2016). Solid biofuel from energy plants is considered at least as "C neutral": $\mathrm{CO}_{2}$ that is released in burning is returned to the biomass from the atmosphere during photosynthesis and returned for a cycle of new growth (Field et al., 2008; Butkute et al., 2015).

Please use the following format when citing the article:

Amaleviciute-Volunge K., Slepetiene A., Butkute B. 2020. The suitability of perennial grasses for combustion as influenced by chemical composition and plant growth stage. Zemdirbyste-Agriculture, 107 (4): 317-322. DOI 10.13080/z-a.2020.107.040 
Perennial grasses have the potential to be used as biofuel crops. However, little is known about which perennial grasses can produce high quantity and high-quality biomass in relation to plant growth stage (Porensky et al., 2014). It has been reported that one of the factors, which influences plant chemical composition, is the degree of plant maturity during harvest (KupryśCaruk et al., 2019). There is a paucity of information about how much energy can be generated from perennial grasses harvested at different times, considering the growth stage.

The aim of this study was to evaluate the suitability of six perennial grass species with a balanced composition of organic compounds and minerals for direct combustion, and to identify plant bioenergy potential for solid fuel production based on the interaction between plant species and growth stage.

\section{Materials and methods}

A field experiment was done in 2018 and 2019 at the Institute of Agriculture $\left(55^{\circ} 23^{\prime} 49^{\prime \prime} \mathrm{N}, 23^{\circ} 51^{\prime} 40^{\prime \prime} \mathrm{E}\right)$, Lithuanian Research Centre for Agriculture and Forestry with six perennial grass species: lucerne (Medicago sativa L.), reed canary grass (Phalaris arundinacea L.), tall fescue (Festuca arundinacea Schreb.), cocksfoot (Dactylis glomerata L.), switchgrass (Panicum virgatum L.) and ryegrass (Lolium perenne L.), grown in $1 \times 0.5 \mathrm{~m}$ plots on a Hypocalcic Stagnic Luvisol (Loamic, Drainic) according to WRB (2015) within three replicates (blocks). Samples were collected for comparison of the influence of harvest time according to plant growth stage on the biomass quality (Table 1). All biomass samples were cut to $1 \mathrm{~cm}$ pieces and fixed at $105^{\circ} \mathrm{C}$ for $20 \mathrm{~min}$, dried at 65 $\pm 5^{\circ} \mathrm{C}$ for $24 \mathrm{~h}$, and ground in a laboratory mill.

Chemical analyses were done at the Chemical Research Laboratory of the Institute of Agriculture, Lithuanian Research Centre for Agriculture and Forestry. Chemical composition of plant samples was determined according to the standard methods as follows: for ash and organic matter content the dried samples were incinerated at $550^{\circ} \mathrm{C}$ temperature. Before testing, the samples of biomass for direct combustion and determination of chemical composition were ground by an ultra-centrifugal mill ZM 200 (Retch, Germany) using $1 \mathrm{~mm}$ mesh size. The content of structural carbohydrates was calculated as differences $($ Cell $)=\mathrm{ADF}-\mathrm{ADL}$, and hemicellulose $($ HCell) $=$ NDF - ADF. Neutral detergent fibre (NDF), acid detergent fibre (ADF) and acid detergent lignin (ADL) in plant biomass were determined using a cell wall detergent fractionation method according to Van Soest et al. (1991) and Slepetiene et al. (2016). NDF and ADF extraction was done on a fibre analyser ANKOM 220 (ANKOM Technology, USA) using filter bags F57 (25- $\mu \mathrm{m}$ porosity). Lignin was determined in beakers on the remaining material from the ADF procedure as a residue insoluble in sulfuric acid $(72 \% \mathrm{w} / \mathrm{w})$. The total organic carbon (C) content was determined by a spectrophotometric measure procedure at the wavelength of $590 \mathrm{~nm}$ using glucose as a standard after wet combustion according to Tyurin method modified by Nikitin (1999). Nitrogen (N) content was determined by the Kjeldahl method using a spectrophotometric measure procedure at the wavelength of $655 \mathrm{~nm}$.

Table 1. Sampling dates and growth stages

\begin{tabular}{lccc}
\hline \multicolumn{1}{c}{ Perennial grass species } & $\begin{array}{c}\text { Heading / inflorescence } \\
\text { emergence }\end{array}$ & Flowering & $\begin{array}{c}\text { Before regrowth } \\
\text { in spring }\end{array}$ \\
\hline Lucerne & 23052018 & 05062018 & 20062018 \\
Reed canary grass & 28052018 & 07062018 & 16082018 \\
Tall fescue & 23052018 & 07062018 & 16082018 \\
Cocksfoot & 16052018 & 28052018 & 20062018 \\
Switchgrass & 10062018 & 27082018 & 10092018 \\
Ryegrass & 23052018 & 07062018 & - \\
\hline
\end{tabular}

The analyses of energy potential. The heating value was measured with a bomb calorimeter IKA C 200 (IKA, Germany) by the $25^{\circ} \mathrm{C}$ temperature dynamic heating test method and expressed as $\mathrm{MJ} \mathrm{kg}^{-1} \mathrm{DM}$. The energy yield (Q) $\left(\mathrm{GJ} \mathrm{ha}^{-1}\right)$ was calculated according to the equation:

$\mathrm{Q}=(\mathrm{Hd} \times \mathrm{Qg}) / 1000$, where $\mathrm{Hd}$ is biomass dry yield, $\mathrm{kg} \mathrm{ha}^{-1}, \mathrm{Qg}-$ heating value, $\mathrm{MJ} \mathrm{kg}^{-1}$.

Statistical analysis. The data structuring analysis and processing were conducted using the software $S A S$, version 9.4 (SAS Institute Inc., USA); $P$ value $<0.05$ was considered statistically significant. The associations between chemical composition and heating value were estimated by Pearson's correlation analysis.

\section{Results and discussion}

The biomass of perennial grasses tested was found to differ in chemical composition, which depended on the plant species and growth stage at harvesting (Table 2).

Table 2 presents the data of grass biomasses obtained at heading / inflorescence emergence stage: ash content $-5.80-9.17 \%, \mathrm{C}-44.62-46.82 \%, \mathrm{~N}$ $1.11-3.45 \%, \mathrm{C}: \mathrm{N}-13.27-42.17 \%$. The highest content of ash $(9.17 \%)$ and $\mathrm{N}(3.45 \%)$ and at the same time the lowest C:N (13.27\%) were recorded in the biomass of lucerne compared with that of other grasses. Biomass of switchgrass was distinguished from other investigated biomasses as having the highest content of $\mathrm{C}(46.82 \%)$ and the highest $\mathrm{C}: \mathrm{N}(42.17 \%)$. Also, the lowest ash $(5.80 \%)$ and $\mathrm{N}$ content was found in the biomass of this grass species at heading / inflorescence emergence stage. These parameters are considered positive for combustion.

Chemical composition of the biomasses tested was analysed at flowering stage: switchgrass and lucerne stood out from the other grass species. The highest content of C $(47.01 \%)$ and $C: N(71.15 \%)$ were determined in the biomass of switchgrass, while the highest concentration of ash $(7.94 \%)$ was established in the biomass of lucerne. The lowest content of ash $(4.91 \%)$ and $\mathrm{N}(0.67 \%)$ was determined in the biomass of switchgrass.

The biomass harvested at the regrowth stage had a similar chemical composition to that harvested at the heading stage, except for ash content, which was the highest $(11.10-8.15 \%)$ at regrowth stage compared with the other growth stages. The biomass of lucerne and switchgrass was exceptional in terms of chemical composition compared with the other investigated perennial grasses. The highest content of ash $(11.10 \%)$ and $\mathrm{N}(2.91 \%)$ and the lowest content of $\mathrm{C}(47.76 \%)$ and $\mathrm{C}: \mathrm{N}(16.43 \%)$ were recorded in the biomass of lucerne. The biomass of switchgrass had the lowest content of ash $(8.15 \%)$ and $\mathrm{N}(1.24 \%)$ and the highest C:N. 
Table 2. The composition of chemical components in perennial grasses at different growth stages

\begin{tabular}{|c|c|c|c|c|}
\hline Perennial grass species & Ash & $\mathrm{C}$ & $\mathrm{N}$ & $\mathrm{C}: \mathrm{N}$ \\
\hline \multicolumn{5}{|l|}{ 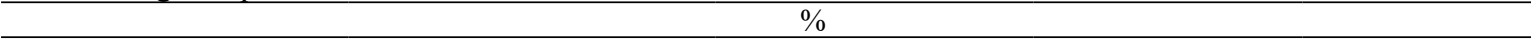 } \\
\hline \multicolumn{5}{|c|}{ Heading / inflorescence emergence } \\
\hline Lucerne & $9.17 \mathrm{aY}$ & $45.76 \mathrm{abZ}$ & $3.45 \mathrm{aX}$ & $13.27 \mathrm{dZ}$ \\
\hline Reed canary grass & $7.43 \mathrm{bY}$ & $46.61 \mathrm{aZ}$ & $2.20 \mathrm{cX}$ & $21.23 \mathrm{cZ}$ \\
\hline Tall fescue & $7.52 \mathrm{bY}$ & $44.67 \mathrm{bW}$ & $2.46 \mathrm{bX}$ & $18.19 \mathrm{cW}$ \\
\hline Cocksfoot & $7.63 \mathrm{bXY}$ & $45.77 \mathrm{abZ}$ & $2.25 \mathrm{cbX}$ & $20.52 \mathrm{cY}$ \\
\hline Switchgrass & $5.80 \mathrm{dY}$ & $46.82 \mathrm{aZ}$ & $1.11 \mathrm{eY}$ & $42.17 \mathrm{aZ}$ \\
\hline Ryegrass & $6.67 \mathrm{cX}$ & $44.62 \mathrm{abZ}$ & $1.59 \mathrm{dX}$ & $28.06 \mathrm{bZ}$ \\
\hline \multicolumn{5}{|c|}{ Flowering } \\
\hline Lucerne & $7.94 \mathrm{aZ}$ & $46.32 \mathrm{aYZ}$ & $1.21 \mathrm{cZ}$ & $38.20 \mathrm{bY}$ \\
\hline Reed canary grass & $6.49 \mathrm{cZ}$ & $46.79 \mathrm{aZ}$ & $1.41 \mathrm{abZ}$ & $33.56 \mathrm{bcY}$ \\
\hline Tall fescue & $6.21 \mathrm{cZ}$ & $46.75 \mathrm{aZ}$ & $1.37 \mathrm{bcZ}$ & $34.12 \mathrm{bcY}$ \\
\hline Cocksfoot & $7.21 \mathrm{bY}$ & $46.71 \mathrm{aZ}$ & $1.56 \mathrm{aY}$ & $30.02 \mathrm{cY}$ \\
\hline Switchgrass & $4.91 \mathrm{dYZ}$ & $47.01 \mathrm{aZ}$ & $0.67 \mathrm{dZ}$ & $71.15 \mathrm{aY}$ \\
\hline Ryegrass & $5.95 \mathrm{cY}$ & $45.61 \mathrm{aY}$ & $1.18 \mathrm{cY}$ & $38.73 \mathrm{bY}$ \\
\hline \multicolumn{5}{|c|}{ Regrowth } \\
\hline Lucerne & $11.10 \mathrm{aX}$ & $47.76 \mathrm{aY}$ & $2.91 \mathrm{aY}$ & $16.43 \mathrm{dZ}$ \\
\hline Reed canary grass & $10.77 \mathrm{aX}$ & $51.16 \mathrm{aY}$ & $1.96 \mathrm{bY}$ & $26.12 \mathrm{cZ}$ \\
\hline Tall fescue & $10.83 \mathrm{aX}$ & $48.71 \mathrm{aY}$ & $1.75 \mathrm{cbY}$ & $28.16 \mathrm{bcz}$ \\
\hline Cocksfoot & $8.45 \mathrm{bX}$ & $49.74 \mathrm{aY}$ & $1.59 \mathrm{cY}$ & $31.52 \mathrm{bY}$ \\
\hline Switchgrass & $8.15 \mathrm{bX}$ & $50.33 \mathrm{aY}$ & $1.24 \mathrm{dX}$ & $40.51 \mathrm{aZ}$ \\
\hline Ryegrass & - & - & - & - \\
\hline \multicolumn{5}{|c|}{ Before regrowth in spring } \\
\hline Lucerne & $5.02 \mathrm{bcW}$ & $55.96 \mathrm{cX}$ & $1.21 \mathrm{aZ}$ & $46.43 \mathrm{eX}$ \\
\hline Reed canary grass & $7.80 \mathrm{aY}$ & $56.07 \mathrm{bcX}$ & $0.79 \mathrm{cW}$ & $70.99 \mathrm{dX}$ \\
\hline Tall fescue & $5.60 \mathrm{bZ}$ & $56.98 \mathrm{abX}$ & $1.04 \mathrm{bW}$ & $55.01 \mathrm{deX}$ \\
\hline Cocksfoot & $5.15 \mathrm{bcZ}$ & $56.83 \mathrm{abcX}$ & $0.66 \mathrm{cdZ}$ & $89.18 \mathrm{bcX}$ \\
\hline Switchgrass & $4.56 \mathrm{cZ}$ & $56.14 \mathrm{bcX}$ & $0.39 \mathrm{eW}$ & $144.56 \mathrm{aX}$ \\
\hline Ryegrass & $4.48 \mathrm{bcZ}$ & $57.55 \mathrm{aX}$ & $0.61 \mathrm{dZ}$ & $93.93 \mathrm{bX}$ \\
\hline
\end{tabular}

Note. The different letters a-e in the column indicate significant differences $(P<0.05)$ in the concentrations of biomass components among grasses at the same growth stage, and the different letters $\mathrm{X}, \mathrm{Y}, \mathrm{Z}$ and $\mathrm{W}$ indicate significant differences $(P<0.05)$ in component concentrations of the same grass species between plant growth stages; $\mathrm{C}$ - organic carbon, $\mathrm{N}-$ nitrogen, $\mathrm{C}: \mathrm{N}-\mathrm{C}$ to $\mathrm{N}$ ratio.

Biomass harvesting before regrowth in spring had the most marked effect on its chemical composition. After winter, the biomass had more C (57.55-55.96\%) and higher $\mathrm{C}: \mathrm{N}(144.56-46.43 \%)$ and less ash $(7.80$ $4.48 \%)$ and $\mathrm{N}(1.21-0.39 \%)$. Three perennial grasses were distinguished from the other grasses tested: lucerne, switchgrass and ryegrass. The biomass of lucerne and switchgrass showed the same trend as at previous harvests: switchgrass had the highest C:N (144.56\%) and the lowest contents of ash $(4.56 \%)$ and $\mathrm{N}(0.39 \%)$.

Summarizing the chemical composition of plants by growth stage, it can be inferred that the biomass harvested before regrowth in spring is the most suitable for direct combustion, since it has a low ash content but a high $\mathrm{C}: \mathrm{N}$. High ash content can cause slagging; this is a problem that herbaceous energy crops pose during combustion. High concentration of $\mathrm{N}$ in combusting biomass can promote greenhouse gas NOx emissions (Baxter, 2011; Butkute et al., 2015). Biomass of ryegrass harvested before regrowth in spring would be a highly suitable raw material for combustion, because it contained more $\mathrm{C}(57.55 \%)$ and less $\mathrm{N}(0.61 \%)$ and ash $(4.48 \%)$ than the other perennial grasses.

Biomass of plants contains varying amounts of cellulose, hemicellulose, lignin and small amounts of lipids, proteins, simple sugars, starches and inorganic constituents and a fraction of water as well (Porensky et al., 2014; Kupryś-Caruk et al., 2019; Nazli, Tansi, 2019). Cellulose, hemicellulose and lignin are the three main constituents of these compounds (Zhang et al., 2010; Saidur et al., 2011; Sosa et al., 2019). One of the most important biomass components for burning is lignin, because it contains a high content of $\mathrm{C}$ (Prochnow et al., 2009; Pociené, Kadžiuliené, 2016). Biomass with high content of lignin is best suited for incineration (Boscaro et al., 2015).

Table 3 shows the contents of fibre components in the biomass at heading/inflorescence stage, flowering, regrowth and before regrowth in spring. The highest content of lignin (19.02\%) was determined in the biomass of lucerne and ryegrass before regrowth in spring. Conversely, the lowest concentration of lignin was found in the biomass of ryegrass at heading stage $(3.97 \%)$ and in the biomass of tall fescue at heading, flowering and regrowth stages 4.02, 4.30 and $4.43 \%$, respectively. Before regrowth in spring, the biomass had higher concentrations of lignin compared with the other growth stages.

In contrast to lignin, cellulose concentration was the lowest in the biomass of lucerne (24.08-24.42\%) at inflorescence emergence and flowering stages. The highest cellulose concentration in the biomass of switchgrass (34.24-36.76\%) was determined at heading and flowering stages. The composition of the biomass of all the tested grasses before regrowth in spring differed from that harvested at the other growth stages. It had the highest concentration of cellulose ranging from 35.51 to $44.21 \%$. Cocksfoot and switchgrass had the highest cellulose concentration (44.21 and $42.37 \%$ ), while ryegrass had the lowest cellulose concentration $(35.51 \%)$.

Analysis of hemicellulose of the six perennial grasses showed the same trend as cellulose. Lucerne biomass had the lowest concentration of hemicellulose at all four growth stages (2.07-15.45\%). The highest amount of hemicellulose was determined in the biomass of switchgrass $(26.45-30.54 \%)$.

The biomass of lucerne, ryegrass and tall fescue harvested before regrowth in spring was most suitable for direct combustion, because it had the highest concentration of $\mathrm{C}$, lignin and cellulose and the smallest amounts of ash and N.

Chemical composition analysis of biomass is particularly important for assessing the energy potential of plants. In addition, chemical composition plays an important role in assessing the heating value of biomass. According to the literature (Saidur et al., 2011; Butkute et al., 2015), plant biomass has a heating value ranging from 17 to $21 \mathrm{MJ} \mathrm{kg}^{-1}$. 
Table 3. The content of fibre components in perennial grasses at different growth stages

\begin{tabular}{|c|c|c|c|}
\hline $\begin{array}{c}\text { Perennial grass } \\
\text { species }\end{array}$ & ADL & CEL & $\mathrm{HCel}$ \\
\hline \multicolumn{4}{|l|}{ 20 } \\
\hline \multicolumn{4}{|c|}{ Heading / inflorescence emergence } \\
\hline Lucerne & $10.89 \mathrm{aY}$ & $24.42 \mathrm{dZ}$ & $2.07 \mathrm{dZ}$ \\
\hline Reed canary grass & $4.67 \mathrm{bcZ}$ & $33.08 \mathrm{aY}$ & $24.96 \mathrm{bX}$ \\
\hline Tall fescue & $4.02 \mathrm{cY}$ & $27.30 \mathrm{cZ}$ & $20.88 \mathrm{cX}$ \\
\hline Cocksfoot & $4.18 \mathrm{cZ}$ & $29.04 \mathrm{bZ}$ & $22.04 \mathrm{cX}$ \\
\hline Switchgrass & $5.70 \mathrm{bZ}$ & $34.24 \mathrm{aZ}$ & $30.54 X$ \\
\hline Ryegrass & $3.97 \mathrm{cZ}$ & $28.85 \mathrm{bZ}$ & $20.68 \mathrm{c} \mathrm{X}$ \\
\hline \multicolumn{4}{|c|}{ Flowering } \\
\hline Lucerne & $8.61 \mathrm{aZY}$ & $27.46 \mathrm{dY}$ & $7.65 \mathrm{cY}$ \\
\hline Reed canary grass & $5.71 \mathrm{cY}$ & $34.31 \mathrm{bY}$ & $23.54 \mathrm{bX}$ \\
\hline Tall fescue & $4.30 \mathrm{eY}$ & $30.71 \mathrm{cY}$ & $21.75 \mathrm{bX}$ \\
\hline Cocksfoot & $5.35 \mathrm{cdY}$ & $34.05 \mathrm{bY}$ & $22.92 \mathrm{bX}$ \\
\hline Switchgrass & $7.07 \mathrm{bY}$ & 36.76 aY & $29.20 \mathrm{aXY}$ \\
\hline Ryegrass & $4.92 \mathrm{deY}$ & $30.95 \mathrm{cY}$ & $23.80 \mathrm{bX}$ \\
\hline \multicolumn{4}{|c|}{ Regrowth } \\
\hline Lucerne & $10.45 \mathrm{aY}$ & $24.08 \mathrm{dZ}$ & $6.55 \mathrm{cY}$ \\
\hline Reed canary grass & $4.43 \mathrm{cZ}$ & $29.82 \mathrm{bZ}$ & $25.04 \mathrm{abX}$ \\
\hline Tall fescue & $4.58 \mathrm{cY}$ & $30.84 \mathrm{bY}$ & $23.04 \mathrm{abX}$ \\
\hline Cocksfoot & $5.66 \mathrm{bY}$ & $27.19 \mathrm{cW}$ & $20.95 \mathrm{bX}$ \\
\hline Switchgrass & $5.74 \mathrm{bZ}$ & $34.49 \mathrm{aZ}$ & $26.68 \mathrm{aY}$ \\
\hline Ryegrass & - & - & - \\
\hline \multicolumn{4}{|c|}{ Before regrowth in spring } \\
\hline Lucerne & $19.02 \mathrm{aX}$ & $41.55 \mathrm{bcX}$ & $15.45 \mathrm{cX}$ \\
\hline Reed canary grass & $9.30 \mathrm{cX}$ & $39.60 \mathrm{cX}$ & $22.33 \mathrm{bX}$ \\
\hline Tall fescue & $9.76 \mathrm{bX}$ & $40.29 \mathrm{cX}$ & $21.26 \mathrm{bX}$ \\
\hline Cocksfoot & $9.27 \mathrm{cX}$ & $44.21 \mathrm{aX}$ & $22.71 \mathrm{bX}$ \\
\hline Switchgrass & $9.15 \mathrm{cX}$ & $42.37 \mathrm{abX}$ & $26.45 \mathrm{aY}$ \\
\hline $\begin{array}{l}\text { Ryegrass } \\
\text { Rysillas }\end{array}$ & $19.02 \mathrm{aX}$ & $35.51 \mathrm{dX}$ & $23.57 \mathrm{bX}$ \\
\hline
\end{tabular}

Explanation under Table 2; ADL - acid detergent lignin, CEL cellulose, $\mathrm{HCel}$ - hemicellulose
Figure 1 shows the heating value of the biomass of 6 perennial grasses at different growth stages: heading, flowering, regrowth and before regrowth in spring.

The results of our experiment show that harvest time determined the differences in the heating value of the investigated grasses. The heating value ranged from 17.7 to $19.02 \mathrm{MJ} \mathrm{kg}^{-1}$ according to grass species and growth stage. It ranged from 18.5 to $19.01 \mathrm{MJ} \mathrm{kg}^{-1}$ at the heading stage, from 18.5 to $18.9 \mathrm{MJ} \mathrm{kg}^{-1}$ at the flowering stage and from 17.7 to $18.7 \mathrm{MJ} \mathrm{kg}^{-1}$ at the regrowth stage. The highest heating value $18.8-19.02 \mathrm{MJ} \mathrm{kg}^{-1}$ was determined in the biomass harvested before regrowth in spring. According to plant chemical composition and heating value, it can be inferred that biomass of lucerne generated most energy at all growth stages: $19.01 \mathrm{MJ} \mathrm{kg}^{-1}$ at the heading stage, $18.9 \mathrm{MJ} \mathrm{kg}^{-1}$ at the flowering stage, $18.7 \mathrm{MJ} \mathrm{kg}^{-1}$ at the regrowth stage and $19.02 \mathrm{MJ} \mathrm{kg}^{-1}$ before regrowth in spring. The heating value of cocksfoot biomass was $18.8 \mathrm{MJ} \mathrm{kg}^{-1}$ at the heading stage, $18.7 \mathrm{MJ}$ $\mathrm{kg}^{-1}$ at the flowering stage, $18.4 \mathrm{MJ} \mathrm{kg}^{-1}$ at the regrowth stage and $19.0 \mathrm{MJ} \mathrm{kg}^{-1}$ before regrowth in spring. The lowest heating value was determined for the biomass of ryegrass. The heating value of tall fescue biomass was 17.7 $\mathrm{MJ} \mathrm{kg}^{-1}$ at the regrowth stage, but before regrowth in spring it was $19.01 \mathrm{MJ} \mathrm{kg}^{-1}$. The results of the heating value showed that the differences were influenced by growth stage of plants. All biomasses had the highest heating value at heading stage and before regrowth in spring compared with flowering and regrowth stages.

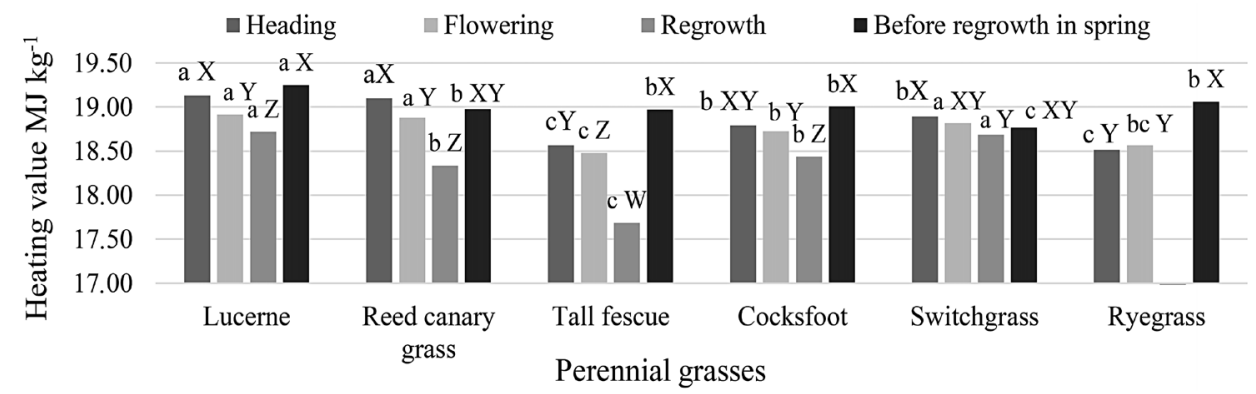

Explanation under Table 2

Figure 1. Heating value of the perennial grasses at different growth stages

In the current study, the energy yield $\left(\mathrm{GJ} \mathrm{h}^{-1}\right)$ of two harvests (heading / inflorescence emergence and regrowth) was calculated based on the heating value and biomass yield (Fig. 2).

Energy yield is a more important indicator of biomass suitability for combustion than biomass yield (Sosa et al., 2019). Like biomass yield, its quality and heating value were affected by grass species and growth stage (Fig. 2). According to the biomass yield and heating value, the biomass of lucerne produced the highest energy yield $303 \mathrm{GJ} \mathrm{ha}^{-1}$ (a sum of two harvests). The biomass of tall fescue produced $185.2 \mathrm{GJ} \mathrm{ha}^{-1}$, and that of cocksfoot 137.3 $\mathrm{GJ} \mathrm{ha}^{-1}$. The biomass of reed canary grass produces lower energy yield - 93.3GJ ha ${ }^{-1}$. A dry summer in 2018 resulted in a low yield of of switchgrass, cocksfoot and ryegrass biomass. The research data obtained reflected the general trend of yield. Different from annual average $18-20 \%$ set in biomasses of cocksfoot, switchgrass and ryegrass, $14-17 \%$ - tall fescue and reed canary grass, and the smallest different were set of lucerne $-9 \%$. These data corroborate the findings of other researchers: Pocienè and Kadžiulienè (2016) have reported that reed canary grass and tall fescue produced 106-122 GJ ha-1.
The lignin content of the biomass is generally strongly correlated with the heating value. The heating value of lignin is higher than that of cellulose and hemicellulose (Saidur et al., 2011; Pocienè, Kadžiulienè, 2016; Nazli, Tansi, 2019). Butkute et al. (2015) have found linear relationships between heating value and $\mathrm{C}$

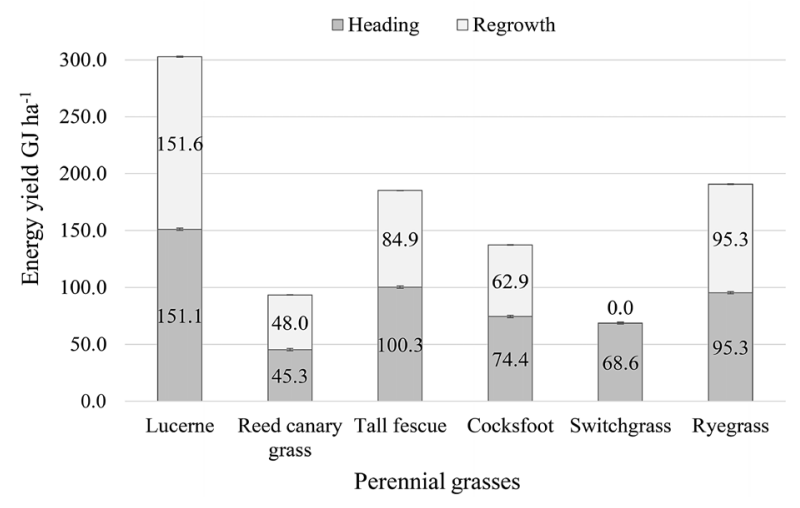

Note. Error bars are shown as standard error.

Figure 2. Energy yield of the biomass of perennial grasses at heading and regrowth stages 
as well as lignin concentration values and also showed that the heating value of lignocellulosic fuels was highly correlated with lignin content.

The results provided in Table 4 show the correlations between biomass chemical composition elements (ash, C, N, C:N, ADL, CEL and HCel) and heating value.

Analysis of the dependence of energy value on chemical composition showed the strongest correlation between heating value and ADL $0.548^{* *}(p<0.01)$ Positive correlation $(p<0.05)$ was found between cellulose $\left(0.376^{*}\right)$ and $\mathrm{C}\left(0.258^{*}\right)$ heating value. It has been demonstrated that the heating value is negatively correlated with the ash content: every $1 \%$ increase in ash content decreases the heating value of a solid fuel by 0.2 $\mathrm{MJ} \mathrm{kg}^{-1}$ (Nazli, Tansi, 2019).

Results of our study confirmed this finding, as negative correlation $(-0.604 * *, p<0.01)$ between the heating value and ash content was found. It was also found that high ash content correlated with $\mathrm{N}$ content $\left(0.641^{* *}, p<0.01\right)$, but negatively correlated with cellulose $(-0.647 * *, p<0.01), \mathrm{C}: \mathrm{N}\left(-0.595^{* *}\right.$, $p<0.01)$ and $\mathrm{C}\left(-0.381^{*}, p<0.05\right)$. There set strong relationship $\mathrm{C}(p<0.01)$ with cellulose $(0.737 * *), \mathrm{C}: \mathrm{N}$ $\left(0.638^{* *}\right)$, lignin $(0.492 * *)$ and weakly correlated with $\mathrm{N}\left(-0.538^{* *}\right)$. The $\mathrm{N}$ content negatively correlated $(p$ $<0.01)$ with $\mathrm{C}: \mathrm{N}(-0.774 * *)$, cellulose $(-0.753 * *)$ and hemicellulose $(-0.494 * *)$. Negative correlation $(p<$ $0.01)$ was determined between lignin and hemicellulose $\left(-0.586^{* *}\right)$, and positive correlation was established between lignin and cellulose $(0.542 * *)$ (Table 3$)$.

The results of the current study are consistent and in line with those of other researchers (Butkute et al., 2015; Kupryś-Caruk et al., 2019; Nazli, Tansi, 2019). Biomass energy potential depends on the chemical composition of plants and harvest time. Plant growth stage determined differences in chemical composition of biomass. Significantly important for combustion

Table 4. Pearson correlations between biomass chemical composition elements and heating value

\begin{tabular}{|c|c|c|c|c|c|c|c|}
\hline & Ash & $\mathrm{C}$ & $\mathrm{N}$ & $\mathrm{C}: \mathrm{N}$ & ADL & CEL & HCel \\
\hline Ash & & & & & & & \\
\hline $\mathrm{C}$ & $-0.381 *$ & & & & & & \\
\hline $\mathrm{N}$ & $0.641 * *$ & $-0.538 * *$ & & & & & \\
\hline $\mathrm{C}: \mathrm{N}$ & $-0.595 * *$ & $0.638 * *$ & $-0.774 * *$ & & & & \\
\hline ADL & $-0.394 \mathrm{~ns}$ & $0.492 * *$ & $-0.080 \mathrm{~ns}$ & $0.172 \mathrm{~ns}$ & & & \\
\hline CEL & $-0.647 * *$ & $0.737 * *$ & $-0.753^{* *}$ & $0.700 * *$ & $0.218 \mathrm{~ns}$ & & \\
\hline HCel & $-0.165 \mathrm{~ns}$ & $0.178 \mathrm{~ns}$ & $-0.494 * *$ & $0.359 *$ & $-0.586^{* *}$ & $0.542 * *$ & \\
\hline $\mathrm{MJ} \mathrm{kg}^{-1}$ & $-0.604 * *$ & $0.258 *$ & $-0.124 \mathrm{~ns}$ & $0.200 \mathrm{~ns}$ & $0.548 * *$ & $0.376^{*}$ & $-0.207 \mathrm{~ns}$ \\
\hline
\end{tabular}

*, ** - significant at $P \leq 0.05$ and $P \leq 0.01, \mathrm{~ns}$ - not significant; $\mathrm{C}$ - organic carbon, $\mathrm{N}$ - nitrogen, $\mathrm{C}: \mathrm{N}-\mathrm{C}$ to $\mathrm{N}$ ratio; $\mathrm{ADL}-$ acid detergent lignin, $\mathrm{CEL}$ - cellulose, $\mathrm{HCel}-$ hemicellulose

is lignin and $\mathrm{C}$ as well as ash and $\mathrm{N}$ content in plants. The highest contents of lignin and $\mathrm{C}$ accumulated in the biomass harvested before regrowth in spring, while $\mathrm{N}$ and ash contents were the lowest. For this reason, it is recommended to use grass biomass harvested at this stage for combustion to produce energy. The biomass of switchgrass, ryegrass and tall fescue is best suited for combustion, because it contains the highest amount of lignin, $\mathrm{C}$ and the lowest amount of ash and $\mathrm{N}$ compared to the other grasses tested. Although lucerne has high amount of lignin and $\mathrm{C}$, it is not recommended to be used for combustion, because its biomass contains high amounts of ash and $\mathrm{N}$.

\section{Conclusions}

1. Of the six grass species tested, lucerne and switchgrass were found to be best suited for direct combustion according to their chemical composition. The biomass of these species contained the highest concentration of lignin and carbon $(\mathrm{C})$ and the smallest concentration of ash and nitrogen $(\mathrm{N})$. The biomass harvested before regrowth in spring was found to have the greatest energy potential compared with that harvested at other growth stages tested.

2. Energy value analysis showed that grass species with high concentrations of lignin and $\mathrm{C}$ in the biomass (lucerne, reed canary grass and switchgrass) had the highest heating value. The biomass harvested before regrowth in spring had the highest heating value and therefore was best suited for direct combustion compared with the biomass harvested at the other growth stages. This was confirmed by correlations: strong correlation between the heating value and acid detergent lignin (ADL) $\left(0.548^{* *}, p<0.01\right)$, positive correlation $(p<0.05)$ with cellulose $\left(0.376^{*}\right)$ and $\mathrm{C}\left(0.258^{*}\right)$, and negative correlation $\left(-0.604^{* *}, p<0.01\right)$ with ash content.

3. Based on annual yields and heating value, it was found that lucerne, tall fescue and ryegrass biomass produced the highest energy yield per hectare.

\section{Acknowledgment}

This project received funding from the European Social Fund (No. 09.3.3-LMT-K-712-02-0061) under grant agreement with the Research Council of Lithuania (LMTLT). Also, a lot of thanks to researchers from Department of Grass Breeding of Institute of Agriculture, Lithuanian Research Centre for Agriculture and Forestry.

Received 19112019 Accepted 14082020

\section{Reference}

1. Baxter L. 2011. Biomass-coal cofiring: an overview of technical issues. P. Grammelis (ed.) Solid biofuels for energy. A lower greenhouse gas alternative. Chapter 3. Springer, p. 43-70. https://doi.org/10.1007/978-1-84996-393-0_3

2. Boscaro D., Pezzuolo A., Grigolato S., Cavalli R., Marinello F., Sartori L. 2015. Preliminary analysis on mowing and harvesting grass along riverbanks for the supply of anaerobic digestion plants in north-eastern Italy. Journal Agricultural Engineering, 46: 100-104 https://doi.org/10.4081/jae.2015.465

3. Butkutè B. Lemežienè N. Kanapeckas J Navickas K Dabkevičius Z., Venslauskas K. 2014. Cocksfoot, tall fescue and reed canary grass: dry matter yield, chemical composition and biomass convertibility to methane. Biomass and Bioenergy, 66: 1-11. https://doi.org/10.1016/j.biombioe 2014.03.014

4. Butkutè B., Liaudanskienè I., Jankauskienè Z. Gruzdevienė E., Cesevičienè J., Amalevičiūtė K. 2015. Features of carbon stock in the biomass of industrial hemp and stinging nettle. A. Sayigh (ed.). Renewable energy in the service of mankind. Vol. I, chapter 2. Springer, p. 17-29. https://doi.org/10.1007/978-3-319-17777-9 2

5. ČerniauskienėZ̆., Raila A. J., Zvicevičius E., Kadžiulienė Ž. Tilvikienè V. 2018. Analysis of Artemisia dubia Wall. growth, preparation for biofuel and thermal conversion properties. Renewable Energy, 118: 468-476. https://doi.org/10.1016/j.renene.2017.11.024

6. De Laporte A. V., Ripplinger D. G. 2019. Economic viability of perennial grass biomass feedstock in northern climates. Industrial Crops and Products, 128: 213-220. https://doi.org/10.1016/j.indcrop.2018.11.013

7. Erol M., Haykiri-Acma M. E. H., Küçükbayrak S. 2010 Calorific value estimation of biomass from their proximate analyses data. Renewable Energy, 35: 170-173. https://doi.org/10.1016/j.renene.2009.05.008 
8. Field C. B., Campbell J. E., Lobell D. B. 2008. Biomass energy: the scale of the potential re-source. Trends Ecology Evolution, 23 (2): 65-72. https://doi.org/10.1016/j.tree.2007.12.001

9. Gaigalis V., Katinas V. 2020. Analysis of the renewable energy implementation and prediction prospects in compliance with the EU policy: a case of Lithuania. Renewable Energy, 151: 1016-1027. https://doi.org/10.1016/j.renene.2019.11.091

10. Kadžiulienė Ž., Tilvikienè V., Liaudanskienè I., Pocienė L. Černiauskiene Ž., Zvicevičius E., Raila A. 2017. Artemisia dubia growth, yield and biomass characteristics for combustion. Zemdirbyste-Agriculture, 104 (2): 99-106. https://doi.org/10.13080/z-a.2017.104.013

11. Kupryś-Caruk M., Podlaski S., Kotyrba D. 2019. Influence of double-cut harvest system on biomass yield, quality and biogas production from $\mathrm{C}_{4}$ perennial grasses. Biomass and Bioenergy, 130: 10537. https://doi.org/10.1016/j.biombioe.2019.105376

12. Nazli R. I., Tansi V. 2019. Influences of nitrogen fertilization and harvest time on combustion quality off our perennial grasses in a semi-arid Mediterranean climate. Industrial Crops and Products, 128: 239-247. https://doi.org/10.1016/j.indcrop.2018.11.019

13. Nikitin B. A. 1999. A method for soil humus determination. Agricultural Chemistry, 3: 156-158 (in Russian).

14. Norkevičienè E., Lemežienè N., Cesevičienè J., Butkutė B. 2016. Switchgrass from North Dakota - a new bioenergy crop in the Nemoral zone of Europe. Communications in Soil Science and Plant Analysis, 47 (1): 64-74. https://doi.org/10.1080/00103624.2016.1232098

15. Pocienè L., Kadžiulienè Ž. 2016. Biomass yield and fibre components in reed canary grass and tall fescue grown as feedstock for combustion. Zemdirbyste-Agriculture, 103 (3): 297-304. https://doi.org/10.13080/z-a.2016.103.038

16. Porensky L. M., Davison J., Leger E. A., Miller W. W., Georgen E. M., Espeland E. K., Carroll-Moore E. M. 2014. Grasses for biofuels: a low water-use alternative for cold desert agriculture? Biomass and Bioenergy, 66: 133-142. https://doi.org/10.1016/j.biombioe.2014.01.046

17. Prochnow A., Heiermann M., Plöchl M., Amon T., Hobbs P. J. 2009. Bioenergy from permanent grassland -a review. 2. Combustion. Bioresource Technology, 100 (21) 4945-4954. https://doi.org/10.1016/j.biortech.2009.05.069
18. Román-Figueroa C., Montenegro N., Paneque M. 2017. Bioenergy potential from crop residue biomass in Araucania Region of Chile. Renewable Energy, 102: 170-177. https://doi.org/10.1016/j.renene.2016.10.013

19. Saidur R., Abdelaziz E. A., Demirbas A., Hossain M. S., Mekhilef S. 2011. A review on biomass as a fuel for boilers. Renewable and Sustainable Energy Reviews, 15: 2262-2289. https://doi.org/10.1016/j.rser.2011.02.015

20. Slepetiene A., Slepetys J., Tilvikiene V., Amaleviciute K., Liaudanskiene I., Ceseviciene J., Kadziuliene Z., Dabkevicius Z., Buliauskaite R.' 2016. Evaluation of chemical composition and biogas production of legumes and perennial grasses in anaerobic digestion using oxitop system. Fresenius Environmental Bulletin, 25(5): 1342-1347.

21. Slepetys J., Kadziuliene Z., Sarunaite L., Tilvikiene V., Kryzeviciene A. 2012. Biomass of plants grown for bioenergy production. Renewable Energy and Energy Efficiency, 11: 66-72.

22. Sosa L. L., Jozami E., Oakley L. J., Montero G. A., Ferreras L. A., Venturi G., Feldman S. R. 2019. Using C perennial rangeland grasses for bioenergy. Biomass and Bioenergy, 128: 105299. https://doi.org/10.1016/j.biombioe.2019.105299

23. Tilvikiene V., Kadziuliene Z., Dabkevicius Z., Venslauskas K., Navickas K. 2016. Feasibility of tall fescue, cocksfoot and reed canary grass for anaerobic digestion: analysis of productivity and energy potential. Industrial Crops and Products, 84: 87-96. https://doi.org/10.1016/j.indcrop.2016.01.033

24. Tilvikienè V., Venslauskas K., Navickas K., Župerka V. Dabkevičius Z., Kadžiulienè Ž. 2012. The biomass and biogas productivity of perennial grasses. ZemdirbysteAgriculture, 99 (1): 17-22.

25. Van Soest P. J., Robertson J. B., Lewis B. A. 1991. Methods for dietary fiber, neutral detergent fiber, and nonstarch polysaccharides in relation to animal nutrition. Journal of Dairy Science, 74 (10): 3583-3597.

https://doi.org/10.3168/jds.S0022-0302(91)78551-2

26. WRB. 2015. World reference base for soil resources. World Soil Resources Reports No. 106. FAO, $189 \mathrm{p}$

27. Zhang K., Johnson L., Vara Prasad P.V., Pei Z., Yuan W., Wang D. 2010. Comparison of big bluestem with other native grasses: chemical composition and biofuel yield. Energy, 83: 358-365.

https://doi.org/10.1016/j.energy.2015.02.033

ISSN 1392-3196 / e-ISSN 2335-8947

Zemdirbyste-Agriculture, vol. 107, No. 4 (2020), p. 317-322

DOI $10.13080 / \mathrm{z}-\mathrm{a} .2020 .107 .040$

\title{
Daugiamečių žolinių augalų tinkamumo biokurui nustatymas vertinant jų cheminę sudètị ir augimo tarpsnius
}

\author{
K. Amalevičiūtè-Volungè, A. Šlepetienè, B. Butkutė \\ Lietuvos agrarinių ir miškų mokslų centro Žemdirbystès institutas
}

\section{Santrauka}

Eksperimento tikslas - nustatyti ir ịvertinti subalansuotos organinès bei mineralinès sudèties augalų rūšių: mèlynžiedès liucernos (Medicago sativa L.), nendrinio dryžučio (Phalaris arundinacea L.), nendrinio eraičino (Festuca arundinacea Schreb.), paprastosios šunažolès (Dactylis glomerata L.), rykštėtosios soros (Panicum virgatum L.) ir daugiametès svidrès (Lolium perenne L.), tinkamumą deginimui, priklausomai nuo augalo rūšies ir pjūties laiko. Atolo ir plaukejjimo / butonizacijos tarpsniais tirtų augalų biomasès cheminè sudètis buvo panaši. Po žiemos augalų biomasejje susikaupia daugiau anglies, lignino bei celiuliozès ir kartu mažiausi kiekiai pelenų bei azoto, todèl iš daugiamečių žolinių augalų deginimui yra tinkamos mėlynžiedès liucernos, nendriniai eraičinai ir ypač daugiametės svidrès, nes jų biomaseje nustatyti didžiausi $\mathrm{C}(57,55 \%)$ ir mažiausi N $(0,61 \%)$ bei pelenų $(4,48 \%)$ kiekiai.

İvertinus energinę vertę nustatyta, kad ją lèmè skirtingi augalų augimo tarpsniai ir cheminė sudètis. Augalų biomasė plaukèjimo / butonizacijos tarpsniu ir po žiemos yra didesnès energinès vertès nei žydejjimo arba atolo tarpsniais. Augalu (dviejų pjūčių) derliaus duomenimis, didžiausią energijos išeigą iš hektaro duoda mèlynžiedžių liucernų biomasè - $303 \mathrm{GJ}$ ha $^{-1}$. Iš nendrinių eraičinų biomasès galima išgauti $185,2 \mathrm{GJ} \mathrm{ha}^{-1}$, iš paprastuju šunažolių - 137,3 $\mathrm{GJ}$ ha $^{-1}$, mažiausiai - iš nendrinių dryžučių - 93,3 GJ ha ${ }^{-1}$. Ivertinus augalų biomasès cheminę sudètį ir gautą energinę vertę, nustatyta stipri koreliacija tarp energinès vertès ir lignino $\left(0,548^{* *}\right.$, $p<0,01)$; energinè vertè taip pat priklauso $(p<0,05)$ nuo celiuliozès $\left(0,376^{*}\right)$ ir anglies $\left(0,258^{*}\right)$ kiekio biomasèje. 